Науковий вісник НЛтУ України Scientific Bulletin of UNFU

https://nv.nltu.edu.ua

https://doi.org/10.36930/40290910

Article received 12.11.2019 p.

Article accepted 26.12.2019 p.

UDK 630*546.36.027:582.572.232(477.42)
ISSN 1994-7836 (print)

ISSN 2519-2477 (online)

$@ \bowtie$ Correspondence author

V. P. Krasnov

volodkrasnov@gmail.com

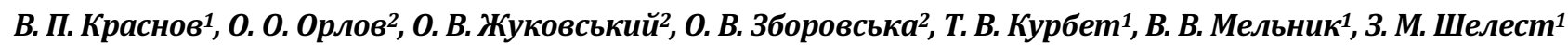

${ }^{1}$ Держсавний університет "Житомирська політехніка", м. Житомир, Украӥна

${ }^{2}$ Поліський філіал УкрНДІЛГА ім. Г. М. Висоиького, с. Довжик, Украйна

\title{
РАДІОАКТИВНЕ ЗАБРУДНЕННЯ КОНВАЛІЇ ЗВИЧАЙНОЇ (CONVALLARIA MAJALIS L.) У ЛІСАХ ЖИТОМИРСЬКОГО ПОЛІССЯ
}

Наведено результати досліджень з вивчення динаміки радіоактивного забруднення надземної фітомаси конвалії звичайної (Convallaria majalis L.) у вологих сугрудах Житомирського Полісся (1991-2018 рр.). Відзначено зменшення щільності радіоактивного забруднення грунту за період спостережень. На всіх постійних пробних площах встановлено вищі значення питомої активності ${ }^{137} \mathrm{Cs}$ у суцвіттях конвалії звичайної відносно величини цього показника у її траві - в $1,3-2,5$ раза. Встановлено зменшення вмісту ${ }^{137} \mathrm{Cs}$ у траві конвалії звичайної за 27 років (1991-2018рр.) в 11,1-17,3 раза. Виявлено підвищення цього показника в окремі роки та періоди, що пов'язано з погодними умовами конкретного року та, можливо, циклічністю міграції ${ }^{137} \mathrm{Cs}$ у лісовому біогеоценозі. Інтенсивність надходження радіонуклідів до досліджуваних частин конвалії звичайної дещо вища у 1998 р. порівняно з отриманими результатами у 2018 р., проте зберігається співвідношення між обома роками спостережень. Величини коефіціснта переходу радіонукліду як до суцвіть $\left(3,8-8,2 \mathrm{~m}^{2} \cdot \mathrm{\kappa}^{-1} \cdot 10^{-3}\right)$, так $\mathrm{i}$ до трави $\left(1,9-5,1 \mathrm{~m}^{2} \cdot \mathrm{\kappa}^{-1} \cdot 10^{-3}\right)$ конвалії звичайної невеликі, що дає підстави віднести цю рослину до помірних накопичувачів ${ }^{137} \mathrm{Cs}$. 3'ясовано, що на сьогодні у лісовій підстилці вологих сугрудів міститься лише 1,3 \% від сумарної активності ${ }^{137} \mathrm{Cs}$ у грунті, а основна його частина перемістилася у верхній 10-сантиметровий мінеральний шар грунту, і становить - 90,06 \%. Внаслідок встановлено сучасну залежність між щільністю радіоактивного забруднення грунту ${ }^{137} \mathrm{Cs}$ та питомою активністю радіонукліду у траві та суцвіттях конвалії звичайної.

Ключові слова: питома активність; ${ }^{137} \mathrm{Cs}$; конвалія звичайна; дерново-слабопідзолисті грунти; коефіцієнт переходу; суцвіття; трава.

Вступ. Уже в перші роки після аварії на ЧАЕС конвалію звичайну (поряд 3 деякими іншими трав'яними рослинами лісів Полісся України) почали використовувати як своєрідний тест-об'єкт радіоактивного забруднення територій. Це пояснювали тим, що ця рослина достатньо поширена у лісовій та лісостеповій частинах України, які зазнали найбільшого радіоактивного забруднення внаслідок аварії на ЧАЕС. Окрім цього вона часто створює зарості на великих площах, що дає підстави організовувати довготривалі моніторингові спостереження. Об'єкт дослідження - конвалія звичайна, що зростає у вологих сугрудах лісів Житомирського Полісся. Предмет дослідження - особливості накопичення ${ }^{137} \mathrm{Cs}$ конвалією звичайною 3 часу аварії на ЧА-

ЕС. Мета дослідження - встановлення сучасних рівнів радіоактивного забруднення трави та суцвіть конвалії звичайної, а також вивчення динаміки питомої активності ${ }^{137} \mathrm{Cs}$ у надземній фітомасі цієї рослини у вологих сугрудах лісів Житомирського Полісся з часу аварії на ЧАЕС. Завдання досліджень полягало в отриманні сучасних даних про рівні радіоактивного забруднення конвалії звичайної та у їх поєднанні зі вже наявними даними, отриманими на постійних пробних площах у попередні роки. Новизна отриманих матеріалів полягає в тому, що вперше у радіоекології лісових екосистем простежено динаміку радіоактивного забруднення одного із її компонентів упродовж тривалого періоду 3 часу надходження радіонуклідів та їх міграцію у лісо-

\section{Інформація про авторів:}

Краснов Володимир Павлович, д-р с.-г. наук, професор, кафедра екологіï. Email: volodkrasnov@gmail.com

Орлов Олександр Олександрович, канд. біол. наук, ст. наук. співробітник, відділ радіаційної екології лісу. Email: orlov.botany@gmail.com

Жуковський Олег Валерійович, наук. співробітник, лабораторія лісівництва. Email: zh_oleh2183@ukr.net; https://orcid.org/0000-0003-3351-9856

Зборовська Ольга Володимирівна, ст. наук. співробітник, відділ радіаційної екологіï лісу. Email: olga.zborovska@ukr.net; https://orcid.org/0000-0003-1649-0297

Курбет Тетяна Володимирівна, канд. с.-г. наук, доцент, кафедра екологіï. Email: meraviglia@ukr.net; https://orcid.org/0000-0001-7820-4263

Мельник Вікторія Вікторівна, здобувач, кафедра екологіï. Email: melnyk_vika91@ukr.net; https://orcid.org/0000-0002-3551-5085

Шелест Зоя Михайлівна, канд. біол. наук, доцент, кафедра екологіï. Email: szm05121960@gmail.com

Цитування за ДСтУ: Краснов В. П., Орлов О. О., Жуковський О. В., Зборовська О. В., Курбет Т. В., Мельник В. В., Шелест З. М. Радіоактивне забруднення конвалії звичайної (Convallaria Majalis L.) у лісах Житомирського Полісся. Науковий вісник НЛтУ України. 2019, т. 29, № 9. С. 60-64.

Citation APA: Krasnov, V. P., Orlov, O. O., Zhukovsky, O. V., Zborovska, O. V., Kurbet, T. V., Melnyk, V. V., \& Shelest, Z. M. (2019). Radioactive contamination of lily-of-the valley (Convallaria Majalis L.) in Zhytomyr Polissia forests. Scientific Bulletin of UNFU, 29(9), 60-64. https://doi.org/10.36930/40290910 
вих грунтах (1986-2018рр.). Отримані результати значно розширюють наші уявлення щодо перерозподілу ${ }^{137} \mathrm{Cs}$ у лісових біогеоценозах у часі та можуть бути використані у практиці ведення заготівлі лікарської сировини. У цьому контексті потрібно розглядати й актуальність проведених досліджень.

Матеріали і методи дослідження. Дослідження проводили на 8 постійних пробних площах (ППП), які було закладено в 1991 р. у лісових насадженнях Лугинського, Липникського та Радогощанського лісництв ДП "Лугинське лісове господарство". Це лісогосподарське підприємство розташоване у північній частині Житомирської області. На його території існують лісові насадженнях, які віднесені до всіх наявних зон радіоактивного забруднення. Розмір ППП - 50×50 м.

Постійні пробні площі розташовані у вологих сугрудах, в яких зростали штучні сосново-дубові лісові насадження віком 40-50 років (на період закладки) 3 невеликою участю берези повислої (Betula pendula Roth.) та осики (Populus tremula L.). Співвідношення листяних i хвойних деревних порід - 70-30\%. Підріст на ППП середньої густоти складався із берези повислої, осики і рідше із сосни звичайної (Pinus sylvestris L.) та дуба звичайного (Quercus robur L.). Підлісок рідкий і складався з горобини звичайної (Sorbus aucuparia L.) та крушини ламкої (Frangula alnus Mill.). Живий надгрунтовий покрив добре розвинений (проективне покриття 65-90 \%) і складався 3: конвалії звичайної (Convallaria majalis L.) - 30-60\%, купини пахучої (Polygonatum odoratum (Mill)) (3-5 \%), перлівки пониклої (Melica nutans L.) - 1-2 \%, буквиці лікарської (Betonica officinalis L.) - 1-3\%, перстача білого (Potentilla alba L.) - 1$3 \%$, орляка звичайного (Pteridium aquilinum (L.) Kuhn.) - 1-3\%, суниць лісових (Fragaria vesca L.) - 1$3 \%$ та численних інших видів (близько 30), поширення яких було незначне. Асоціація: сосново-дубовий ліс конвалієво-різнотравний. Грунт - дерново-слабопідзолистий супіщаний.

У межах кожної ППП, за допомогою сітки Раменського, закладали 10 облікових ділянок площею $1 \mathrm{~m}^{2}$ $(1 \times 1$ м) (у 2018 р. для вивчення трави - 6, суцвіть 3 облікові ділянки). Облікові ділянки розташовувались на ППП рандомізовано (Ramensky, 1971). На облікових ділянках зрізали всю надземну фітомасу конвалії звичайної та відбирали грунт методом конверту (буром діаметром $5 \mathrm{~cm}$ у п'яти точках на глибину $10 \mathrm{~cm})$. Далі надземну фітомасу розділяли на суцвіття та пагони 3 листками (траву), які окремо подрібнювали і висушували та аналізували на багатоканальному гамма-спектроаналізаторі імпульсів СЕГ-005-АКП із сцинтиляційними детекторами БДЕГ-20-Р1 та БДЕГ-20-Р2. Середня відносна похибка вимірювання активності радіонукліду становила $\pm 8 \%$ (довірчий рівень - 0,95). Результати досліджень обробляли за допомогою пакета прикладних програм Microsoft Office Excel та Statistic 10 (Dospekhov, 1985). Упродовж 1991-2006 pp. дослідження проводили щорічно, а далі - через 2-5 років).

Аналіз літературних джерел. Відомо, що конвалія звичайна - це невисока, 20-30 см заввишки трав'яна рослина, яка росте у мішаних соснових і листяних лісових насадженнях відзначених вище природних зон. Окрім цього, вона трапляється у Карпатах і північній частині Степу. Конвалія звичайна - тіньовитривала росли- на, яка утворює довге, багаторічне кореневище, на якому розміщені бруньки відновлення. 3 останніх щорічно формуються надземні пагони з листками. Від кореневища відходять дрібні, мичкуваті корені (Morozyuk \& Protopopova, 2007). У лісовій типології конвалію звичайну використовують як індикатор свіжих і вологих сугрудів і грудів, але ця рослина трапляється також і в інших лісорослинних умовах - свіжих і вологих суборах (Elin \& Meshcheryakov, 1793). Поширення цього виду у багатьох типах лісорослинних умов дало змогу радіоекологам досліджувати темпи надходження радіонуклідів у різних екологічних умовах (Krasnov et al., 2004). В Україні, безпосередньо після аварії на ЧАЕС, були організовані дослідження щодо вивчення особливостей накопичення ${ }^{137} \mathrm{Cs}$ деякими видами лікарських рослин. Радіоекологи вибрали найпоширеніші у лісах Полісся України види рослин, а також ті, заготівля яких проводилась у найбільших об'ємах (Krasnov et al., 2004). Конвалію звичайну також використовують в офіціальній і народній медицині (Chopik et al., 1983; Minarchenko, 2005), і тому була залучена до вивчення. Перші результати дали змогу дослідникам відзначити невеликі рівні радіоактивного забруднення надземної фітомаси конвалії звичайної. Далі дослідники вивчали вміст ${ }^{137} \mathrm{Cs}$ у конвалії звичайної у різних типах лісорослинних умов (Krasnov et al., 2004), а також динаміку питомої активності радіонукліду у суцвіттях і траві даної рослини (Krasnov et al., 2011). Було встановлено поступове зниження цього показника впродовж періоду спостережень - 1991-2008 рр. Також виявили залежність між питомою активністю ${ }^{137} \mathrm{Cs}$ у суцвіттях і траві конвалії звичайної та складовими радіаційної ситуації (щільністю радіоактивного забруднення грунту, експозиційною дозою гамма-випромінювання). У публікації також запропоновано практичні рекомендації щодо заготівлі: заготівлю суцвіть конвалії рекомендували на площах зі щільністю радіоактивного забруднення грунту до $1,8 \mathrm{Ki} / \mathrm{\kappa м}^{2}$, а трави - до 2,2 Кi//м².

У Білорусі вивчали рівні радіоактивного забруднення найпоширеніших видів лісових трав'яних рослин різних ценозів, у деяких типах лісу автоморфних і гідроморфних ландшафтів, а також розподіл радіонукліду у частинах і органах (Eliashevich, 1992; Ermakova, 2000). Дослідники побудували ряди, у яких розмістили види рослин у порядку збільшення коефіцієнтів переходу ${ }^{137} \mathrm{Cs}$ до них, а також у порядку збільшення питомої активності радіонукліду. У публікаціях відзначали невеликі рівні вмісту ${ }^{137} \mathrm{Cs}$ у надземній фітомасі конвалії звичайної, а також концентрацію радіонукліду у бруньках поновлення та сисних коренях (Zabolotny, 2000).

Результати дослідження та їх обговорення. Постійні пробні площі характеризуються схожими екологічними умовами, але мають різну щільність радіоактивного забруднення грунту. Мінімальні значення цього показника у 2018 р. на ППП-5 становлять

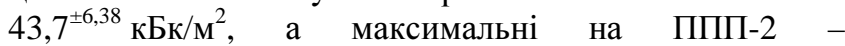
$414,8^{ \pm 33,63}$ кБк/м² (табл. 1). Це дає змогу продовжити пошук залежностей між щільністю радіоактивного забруднення грунту та питомою активністю радіонукліду у надземній частині конвалії звичайної. На всіх ППП спостерігається зменшення щільності радіоактивного забруднення грунту за період спостережень (1991- 
2018 рр.). Так, на ППП-5 (мінімальні значення) цей показник зменшився у 2,5 раза (3 $111,0^{ \pm 6,32}$ кБк/м ${ }^{2}$ до $43,7^{ \pm 6,38}$ кБк/м²), на ППП-2 (максимальні значення) у 2,6 раза $\left(1110,0^{ \pm 74,4} \kappa Б \kappa / \mathrm{M}^{2}\right.$ до $419,8^{ \pm 33,63} \kappa$ кК/ $\left.\mathrm{M}^{2}\right)$. Зменшення щільності радіоактивного забруднення грунту пояснюється, в першу чергу, розпадом радіонукліду, а також, але меншою мірою, знаходженням його частини у всіх рослинах лісового фітоценозу.

Табл. 1. Питома активність і коефіцієнти переходу ${ }^{137} \mathrm{Cs}$ у траві та суцвіттях конвалії звичайної на ППП у 2018 р.

\begin{tabular}{|c|c|c|c|c|c|}
\hline \multirow[b]{2}{*}{$\begin{array}{c}\text { № } \\
\text { ППП }\end{array}$} & \multirow{2}{*}{$\begin{array}{c}\text { Щільність радіоактивного } \\
\text { забруднення грунту }{ }^{137} \mathrm{Cs}, \\
\text { кБк/м }{ }^{2}\end{array}$} & \multicolumn{2}{|c|}{ Радіаційні показники трави } & \multicolumn{2}{|c|}{ Радіаційні показники суцвіть } \\
\hline & & $\begin{array}{c}\text { питома активність } \\
{ }^{137} \mathrm{Cs}, \text { Бк/кг }\end{array}$ & КП, м ${ }^{2} \cdot \mathrm{\kappa}^{-1} \cdot 10^{-3}$ & $\begin{array}{c}\text { питома активність } \\
{ }^{137} \mathrm{Cs}, \text { Бк/кг }\end{array}$ & КП, $\mathrm{m}^{2} \cdot \mathrm{K}^{-1} \cdot 10^{-3}$ \\
\hline 5 & $43,7^{ \pm 6,38}$ & $182^{ \pm 13,4}$ & $4,7^{ \pm 0,75}$ & $301^{ \pm 6,9}$ & $6,9^{ \pm 0,16}$ \\
\hline 3 & $50,8^{ \pm 2,73}$ & $257^{ \pm 27,4}$ & $5,1^{ \pm 0,45}$ & $414^{ \pm 10,5}$ & $8,2^{ \pm 0,21}$ \\
\hline 6 & $71,0^{ \pm 4,73}$ & $276^{ \pm 24,0}$ & $4,0^{ \pm 0,56}$ & $455^{ \pm 54,6}$ & $6,4^{ \pm 0,77}$ \\
\hline 4 & $96,3^{ \pm 7,79}$ & $365^{ \pm 45,3}$ & $3,8^{ \pm 0,33}$ & $487^{ \pm 62,5}$ & $5,1^{ \pm 0,65}$ \\
\hline 7 & $191,1^{ \pm 8,30}$ & $455^{ \pm 30,7}$ & $2,4^{ \pm 0,23}$ & $804^{ \pm 82,1}$ & $4,2^{ \pm 0,43}$ \\
\hline 8 & $221,3^{ \pm 25,07}$ & $476^{ \pm 52,2}$ & $2,2^{ \pm 0,09}$ & $1213^{ \pm 96,7}$ & $5,5^{ \pm 0,44}$ \\
\hline 1 & $357,1^{ \pm 28,06}$ & $705^{ \pm 83,6}$ & $2,0^{ \pm 0,14}$ & $1351^{ \pm 139,5}$ & $3,8^{ \pm 0,39}$ \\
\hline 2 & $414,8^{ \pm 33,63}$ & $772^{ \pm 76,9}$ & $1,9^{ \pm 0,05}$ & $1703^{ \pm 84,8}$ & $4,1^{ \pm 0,20}$ \\
\hline
\end{tabular}

Джерело: результати отримали автори.

На всіх ППП у 2018 р. спостерігаються дещо вищі значення питомої активності ${ }^{137} \mathrm{Cs}$ у суцвіттях конвалії звичайної відносно величини цього показника у іï траві - в 1,3-2,5 раза. Це, напевно, можна пояснити деякими біологічними особливостями формування органів рослини, оскільки подібну закономірність відзначено у всі роки наших спостережень. Відповідно і величини коефіцієнта переходу, отримані у 2018 р., дещо вищі для суцвіть, ніж для трави конвалії звичайної. Так, на ППП-5 коефіцієнт переходу для суцвіть становив $6,9^{ \pm 0,16} \mathrm{M}^{2} \cdot \mathrm{\kappa}^{-1} \cdot 10^{-3}$, а для трави $-4,7^{ \pm 0,75} \mathrm{M}^{2} \cdot \kappa \Gamma^{-1} \cdot 10^{-3} ;$ на ППП-3 - 8,2 $2^{ \pm 0,21} \mathrm{M}^{2} \cdot \kappa \Gamma^{-1} \cdot 10^{-3} \mathrm{i} 5,1^{ \pm 0,45} \mathrm{M}^{2} \cdot \mathrm{\kappa}^{-1} \cdot 10^{-3}$ (відповідно); на ППП-6 - 6,4 $4^{ \pm 0,77} \mathrm{M}^{2} \cdot \mathrm{K \Gamma}^{-1} \cdot 10^{-3} \mathrm{i} 4,0^{ \pm 0,56} \mathrm{M}^{2} \cdot \mathrm{K}^{-1} \cdot 10^{-3}$; на ППП-4 - 5, $1^{ \pm 0,65} \mathrm{M}^{2} \cdot \mathrm{K \Gamma}^{-1} \cdot 10^{-3} \mathrm{i} 3,8^{ \pm 0,33} \mathrm{M}^{2} \cdot \mathrm{K}^{-1} \cdot 10^{-3}$; на ППП-7 - 4,2 $2^{ \pm 0,43} \mathrm{M}^{2} \cdot \mathrm{\kappa \Gamma}^{-1} \cdot 10^{-3} \mathrm{i} 2,4^{ \pm 0,23} \mathrm{M}^{2} \cdot \mathrm{\kappa \Gamma}^{-1} \cdot 10^{-3}$; на ППП$8-5,5^{ \pm 0,44} \mathrm{M}^{2} \cdot \mathrm{\kappa} \Gamma^{-1} \cdot 10^{-3} \mathrm{i} 2,2^{ \pm 0,09} \mathrm{M}^{2} \cdot \mathrm{K}^{-1} \cdot 10^{-3}$; на ППП-1 $3,8^{ \pm 0,39} \mathrm{M}^{2} \cdot \mathrm{K}^{-1} \cdot 10^{-3} \mathrm{i} \quad 2,0^{ \pm 0,14} \mathrm{M}^{2} \cdot \mathrm{K}^{-1} \cdot 10^{-3} ; \quad$ на ППП-2 $4,1^{ \pm 0,20} \mathrm{M}^{2} \cdot \kappa \Gamma^{-1} \cdot 10^{-3}$ i $1,9^{ \pm 0,05} \mathrm{M}^{2} \cdot \kappa \Gamma^{-1} \cdot 10^{-3}$ (відповідно). Це перевищення сягало 2,5 разів (ППП-8). Треба зазначити, що величини коефіцієнта переходу радіонукліду як до суцвіть $\left(3,8-8,2 \mathrm{M}^{2} \cdot \mathrm{\kappa}^{-1} \cdot 10^{-3}\right)$, так і до трави $(1,9$ $\left.5,1 \mathrm{~m}^{2} \cdot \kappa \Gamma^{-1} \cdot 10^{-3}\right)$ конвалії звичайної невеликі, що дає підстави віднести цю рослину до помірних накопичувачів ${ }^{137} \mathrm{Cs}$.

Коефіцієнти переходу ${ }^{137} \mathrm{Cs}$ до суцвіть і трави конвалії звичайної, які отримано у 1998 р., дещо вищі (максимальні значення), на відміну від тих, які аналізували (2018 р.). Так, величина коефіцієнта переходу до суцвіть була у межах $4,2^{ \pm 0,7}-13,3^{ \pm 3,9} \mathrm{M}^{2} \cdot \kappa \Gamma^{-1} \cdot 10^{-3}$, а у траву $2,2^{ \pm 0,3}-8,2^{ \pm 0,7} \mathrm{M}^{2} \cdot \kappa^{-1} \cdot 10^{-3}$. Втім співвідношення першого показника до другого в обидва роки спостережень дуже схожі: у 1998 р. - 1,4-2,5 раза, а у 2018 р. - 1,3-2,5 раза. Це також частково вказує на біологічні особливості накопичення цього радіонукліду (хімічним аналогом якого є калій) у суцвіттях і траві (пагони та листки) конвалії звичайної. Окрім цього, незначне зниження КП за 20-річний період (1998-2018 рр.) вказує на слабке закріплення ${ }^{137} \mathrm{Cs}$ у грунті.

Моніторингові спостереження за питомою активністю ${ }^{137} \mathrm{Cs}$ у надземній частині конвалії звичайної вказує на поступове іï зменшення впродовж періоду спостережень (рис. 1). Це пояснюють розпадом радіонукліду, деяким більш жорстким закріпленням у грунті та переміщенням до інших компонентів лісових біоценозів. Водночас необхідно зазначити, що в окремі роки та періоди спостерігається збільшення величини питомої ак- тивності у суцвіттях і траві конвалії звичайної. Перше можна пояснити погодними умовами, які призводять до збільшення інтенсивності надходження ${ }^{137} \mathrm{Cs}$ до рослин, а друге, напевно, циклічністю міграції радіонукліду у лісових біогеоценозах. Циклічність пов'язана 3 періодами інтенсивного надходження ${ }^{137} \mathrm{Cs}$ до лісових рослин, його поверненням на поверхню грунту з опадом хвої, листків, частин кори і пагонів багаторічних рослин, надземною частиною однорічних і дворічних рослин; його заглибленням до насиченого коренями шару грунту та, знову ж, інтенсивнішим надходженням до рослин.

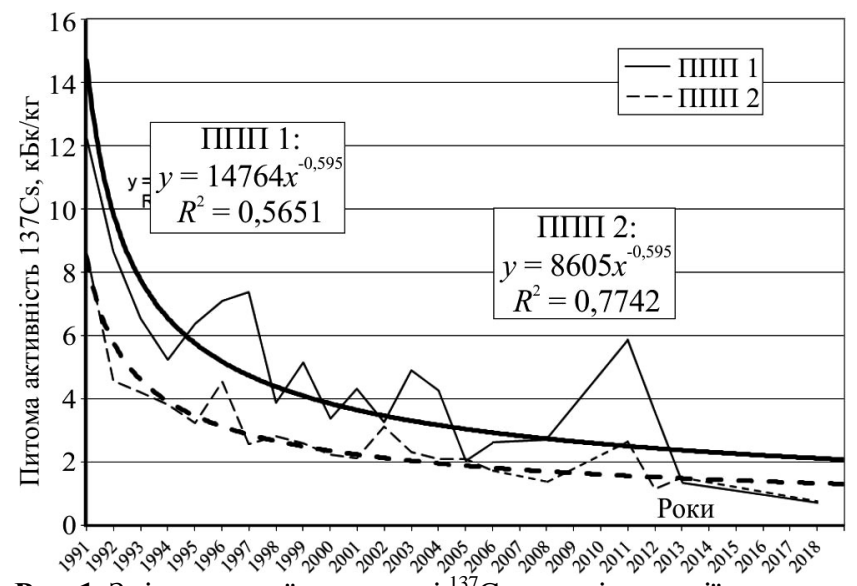

Рис. 1. Зміна питомої активності ${ }^{137} \mathrm{Cs}$ у траві конвалії звичайної впродовж 1991-2018 рр. на ППП-1 та ППП-2. Джерело: результати отримали автори

На ППП-1 спостерігається зниження питомої активності ${ }^{137} \mathrm{Cs}$ у траві конвалії звичайної з 1991 р. по 1994 р. в 1,5 раза (від $12188^{ \pm 1156}$ Бк/кг до $5225^{ \pm 436}$ Бк/кг), у наступні роки (до 1997 р.) простежується ії збільшення до $7368^{ \pm 723}$ Бк/кг (в 1,4 раза порівняно 31994 р.). Схожі підвищення цього показника ми відзначали і далі в окремі роки та періоди - 1999, 2003-2004, 20052011 рр. Загалом за період спостережень 31991 р. по 2018 р. цей показник на ППП-1 зменшився у 17,3 раза від $12188^{ \pm 1156}$ Бк/кг до $705^{ \pm 83,6}$ Бк/кг. Це зниження описується ступеневою функцією, яка є від'ємною та достатньо тісною. Подібні тенденції і схожі коливання питомої активності ${ }^{137} \mathrm{Cs}$ у траві та суцвіттях конвалії звичайної виявлено і на інших ППП.

Зниження питомої активності ${ }^{137} \mathrm{Cs}$ у конвалії звичайній за період спостережень пояснюють передусім зниженням щільності радіоактивного забруднення грун- 
ту (у 2,5-3,0 рази залежно від ППП). Своєю чергою, зниження останньої відбулося внаслідок природного розпаду радіонукліду, його переміщення до інших компонентів лісових біогеоценозів i, можливо, за рахунок переміщення за межі розміщення кореневої системи конвалії звичайної. Для підтвердження останнього припущення ми проаналізували розподіл сумарної активності ${ }^{137} \mathrm{Cs}$ у різних шарах грунту (табл. 2).

Табл. 2 Сумарна активність ${ }^{137} \mathrm{Cs}$ у шарах грунту вологих сугрудів на ППП-1 у 2017 р. (площа 500 см$^{2}$ )

\begin{tabular}{|c|c|c|}
\hline $\begin{array}{c}\text { Грунтовий } \\
\text { горизонт }\end{array}$ & $\begin{array}{c}\text { Сумарна активність } \\
{ }^{377} \mathrm{Cs}, \text { Бк/500 } \mathrm{cm}^{2}\end{array}$ & $\begin{array}{c}\text { Частка сумарної ак- } \\
\text { тивності }{ }^{137} \mathrm{Cs}, \%\end{array}$ \\
\hline Но нерозкладена & 15 & 0,11 \\
\hline Но напіврозкладена & 67 & 0,50 \\
\hline Но розкладена & 93 & 0,69 \\
\hline $0-2$ см & 6694 & 49,74 \\
\hline $2-4$ см & 2432 & 18,07 \\
\hline $4-6$ см & 1516 & 11,27 \\
\hline $6-8$ см & 1038 & 7,71 \\
\hline $8-10$ см & 440 & 3,27 \\
\hline $10-12$ см & 372 & 2,76 \\
\hline $12-14$ см & 260 & 1,93 \\
\hline $14-16$ см & 181 & 1,34 \\
\hline $16-18$ см & 72 & 0,53 \\
\hline $18-20$ см & 62 & 0,46 \\
\hline $20-22$ см & 54 & 0,40 \\
\hline $22-24$ см & 47 & 0,35 \\
\hline $24-26$ см & 48 & 0,36 \\
\hline $26-28$ см & 39 & 0,29 \\
\hline $28-30$ см & 29 & 0,22 \\
\hline Всього & $\mathbf{1 3 4 5 8}$ & $\mathbf{1 0 0 , 0 0}$ \\
\hline
\end{tabular}

Джерело: результати отримали автори.

Отримані матеріали свідчать, що у лісовій підстилці вологих сугрудів зберігається лише 1,3\% від сумарної активності ${ }^{137} \mathrm{Cs}$ у грунті, а основна його частина перемістилася до мінеральної частини грунту. Із збільшенням глибини цей показник зменшується. Закономірність зменшення описується (рис. 2) рівнянням: $Y=31,778 e^{-0,37 X}$ (ППП-1). Наведена залежність $є$ тісною та достовірною (коефіцієнт детермінації $r^{2}=0,94$ ).

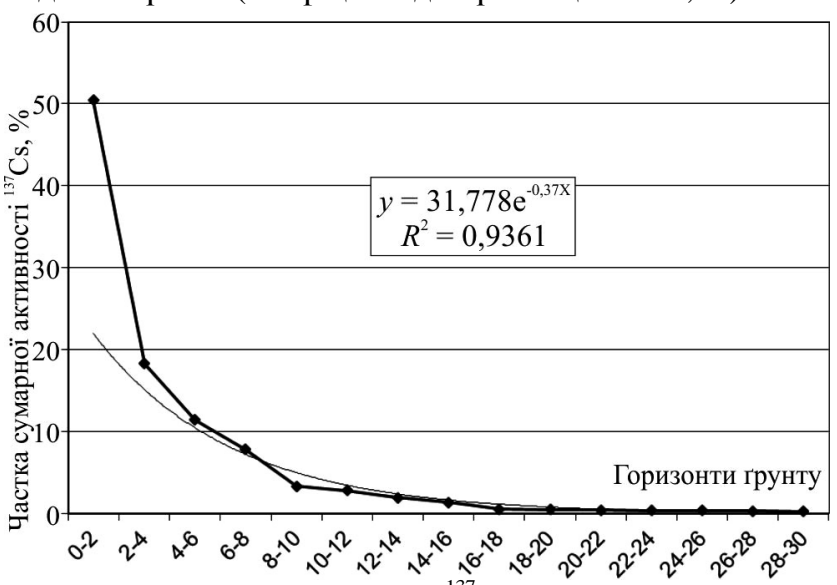

Рис. 2. Зміна сумарної активності ${ }^{137} \mathrm{Cs}$ у мінеральних горизонтах грунту з глибиною у 2017 р. на ППП-1 (ТЛУ $-\mathrm{C}_{3}$ ). Джерело: результати отримали автори

У різні періоди з часу аварії на ЧАЕС ми встановлювали залежність між питомою активністю ${ }^{137} \mathrm{Cs}$ у траві i суцвіттях конвалії звичайної та величиною щільності радіоактивного забруднення грунту. Це дало змогу роз- раховувати можливі рівні вмісту радіонукліді у відзначених частинах конвалії звичайної за певних рівнів радіоактивного забруднення грунту та рекомендувати заготівельним організаціям можливі місця заготівлі цієї лікарської сировини. Розрахунки, проведені з використанням матеріалів 2018 р., показали, що ця залежність апроксимувалася лінійними рівняннями значної тісноти: для суцвіть $-y=3,57+195,97\left(r^{2}=0,91\right)$ і для трави $-y=1,52 x+160,75\left(r^{2}=0,87\right)$.

\section{Висновки:}

1. 3 часу надходження радіонуклідів у період аварії на ЧАЕС до лісових грунтів Полісся України відбулося значне їх заглиблення. На сьогодні у лісовій підстилці вологих сугрудів міститься лише 1,3\% від сумарної активності ${ }^{137} \mathrm{Cs}$ у грунті, а основна його частина перемістилася до мінеральної частини грунту. У верхньому 10сантиметровому шарі мінеральної частини грунту міститься 90,06\% сумарної активності радіонукліду у грунті.

2. Триває достатньо інтенсивне надходження ${ }^{137} \mathrm{Cs}$ з грунту до надземної частини конвалії звичайної. Найбільші величини коефіцієнтів переходу ${ }^{137} \mathrm{Cs} 3$ грунту відзначено для суцвіть (від $3,8^{ \pm 0,39} \mathrm{M}^{2} \cdot \mathrm{\kappa}^{-1} \cdot 10^{-3}$ (ППП-1) до $8,2^{ \pm 0,21} \mathrm{M}^{2} \cdot \mathrm{\kappa}^{-1} \cdot 10^{-3}$ (ППП-3) і дещо менші для трави конвалії звичайної (від 2,0 $0^{ \pm 0,14} \mathrm{M}^{2} \cdot \mathrm{\kappa r}^{-1} \cdot 10^{-3}$ (ППП-1) до $5,1^{ \pm 0,45} \mathrm{M}^{2} \cdot \kappa \Gamma^{-1} \cdot 10^{-3}($ ППП-3).

3. Упродовж періоду спостережень (1991-2018 рр.) відбувається зниження питомої активності ${ }^{137} \mathrm{Cs}$ у суцвіттях та траві конвалії звичайної. У межах усіх пробних площ це зниження коливається від 11,1 (ППП-2) до 17,3 (ППП-1) раза (від 8559 $9^{ \pm 794,0}$ Бк/кг до $772^{ \pm 76,9}$ Бк/кг та з $12188^{ \pm 1156}$ Бк/кг до $705^{ \pm 83,6}$ Бк/кг відповідно).

\section{References}

Chopik, V. I., Dudchenko, L. G., \& Krasnova, A. N. (1983). Wild useful plants of Ukraine. Directory. Kyiv: Scientific thought. [In Russian].

Dospekhov, B. A. (1985). Methodology of field experience. Moscow: Agropromizdat. [In Russian].

Eliashevich, N. V. (1992). Chernobyl accident: pollution of herbaceous plants. Practical aspects. (Ser. Physical and Energy Sciences). News of the Academy of Sciences of Belarus, 1, 5-10. [In Russian].

Elin, E. Y., \& Meshcheryakov, G. I. (1973). Atlas of indicator plants of forests of Ukraine. Kyiv: Harvest. [In Russian].

Ermakova, O. O. (2000). Radioecological monitoring of ${ }^{137} \mathrm{Cs}$ accumulation in plants of living soil cover of forest cenoses. Radioactivity in nuclear explosions and accidents: Report abstract International the Conference, Moscow, April, 24-26, 2000. St. Petersburg: Gidrometeoizdat, 217 p. [In Russian]

Krasnov, V. P, Orlov, A. A., \& Getmanchuk, A. I. (2004). Radioecology of medicinal plants. Zhytomyr: Volyn. [In Ukrainian].

Krasnov, V. P., Kurbet, T. V., \& Orlov, A. A. (2011). Peculiarities of ${ }^{137} \mathrm{Cs}$ accumulation by different organs of Convallaria Majalis L. in the moist sougruds of Polissya of Ukraine. Forestry \& Forest Melioration, 118, 64-73. Kharkiv. [In Ukrainian].

Minarchenko, V. M. (2005). Likarski sudinni roslini of Ukraine (medical and resource value). Kyiv: Phytosociocenter. [In Ukrainian].

Morozyuk, S. S. \& Protopopova, V. V. (2007). Grassy plants of Ukraine. Atlas determinant. Kyiv: The educational book. [In Ukrainian].

Ramensky, L. G. (1971). Problems and methods of studying vegetation. Leningrad: Science. [In Russian].

Zabolotny, A. I. (2000). Migration ${ }^{137} \mathrm{Cs}$ in the soil - plant - soil system involving May lily of the valley and purchased medicinal. Radioactivity in nuclear explosions and accidents: Report abstract at International Conference, Moscow, April, 24-26, 2000. St. Petersburg: Gidrometeoizdat, 215 p. [In Russian]. 


\section{RADIOACTIVE CONTAMINATION OF LILY-OF-THE VALLEY (CONVALLARIA MAJALIS L.) IN ZHYTOMYR POLISSIA FORESTS}

The results of studies of the dynamics of radioactive contamination of terrestrial phytomass of lily of the valley (Convallaria majalis L.) in the wet territories of Zhytomyr Polissya (1991-2018) are presented. A decrease in the density of radioactive contamination of soil during the observation period was noted. Thus, for the sample plots-5 (minimum values) this indicator decreased in 2.5 times (from $111.0^{ \pm 6.32} \mathrm{kBq} / \mathrm{m}^{2}$ to $43.7^{ \pm 6.38} \mathrm{kBq} / \mathrm{m}^{2}$ ), and for the sample plots-2 (maximum value) in 2.6 times $\left(1110.0^{ \pm 74.4} \mathrm{kBq} / \mathrm{m}^{2}\right.$ to $\left.419.8^{ \pm 33.63} \mathrm{kBq} / \mathrm{m}^{2}\right)$. Higher values of the specific activity of ${ }^{137} \mathrm{Cs}$ in inflorescences of the lily-of-the-valley with respect to the value of this indicator in its grass were observed at all the sample plots in 1.3-2.5 times. A reduction of ${ }^{137} \mathrm{Cs}$ in the grass lily of the valley for 27 years (1991-2018) was found to decrease in 11.1-17.3 times. This indicator was found to increase in certain years and periods, which may be related to the weather conditions of a particular year and the cyclical migration of ${ }^{137} \mathrm{Cs}$ in forest biogeocenosis. The intensity of radionuclide inflow into the studied parts of the lily of the valley was slightly higher in 1998 compared to the results obtained in 2018, but the correlation between the two years of observations remains. The values of the radionuclide transition coefficient for both inflorescences $\left(3.8-8.2 \mathrm{~m}^{2} \mathrm{~kg}^{-1} 10^{-3}\right)$ and grass $\left(1.9-5.1 \mathrm{~m}^{2} \mathrm{~kg}^{-1} 10^{-3}\right)$ of lily of the valley are small, which allows classifying this plant as one with moderate storage of ${ }^{137} \mathrm{Cs}$. It has been found that, at present, only $1.3 \%$ of the total ${ }^{137} \mathrm{Cs}$ activity in the soil is contained in the forest litter, and its bulk has moved to the $10 \mathrm{~cm}$ top of the soil mineral layer, and is $90.06 \%$. As a result, a recent relationship was established between the density of radioactive ${ }^{137} \mathrm{Cs}$ contamination of soil and the specific activity of radionuclide in grass and inflorescences of lily of the valley.

Keywords: specific activity; ${ }^{137} \mathrm{Cs}$; lily of the valley; sod low-podzolic soils; conversion rate; inflorescence; grass. 